Financial History Review 27.I (2020), pp. 73-94. (C) European Association for Banking and Financial History e.V. 2020. This is an Open Access article, distributed under the terms of the Creative Commons Attribution licence (http://creativecommons.org/licenses/by/4.o/), which permits unrestricted re-use, distribution, and reproduction in any medium, provided the original work is properly cited. doi:I0.IOI7/So9685650I9000222

\title{
The role of a creditor in the making of a debt crisis: the French government's financial support for Poland, between cold war interests and economic constraints, I958-I98 I
}

\author{
EMMANUEL MOURLON-DRUOL \\ University of Glasgow
}

\begin{abstract}
In spite of considerable attention granted to sovereign debt failures, we still have limited knowledge of the incentives which induced creditors to lend at unsustainable levels. This article looks at the French government's policy towards Poland from 1958, when economic cooperation between the two countries started, until Poland's announcement in I98 I that it could not service its debt. Export credit guarantees supported France's financial involvement, and this implied the government's strong influence on the decision to lend. This article brings out the tension between economic and political priorities in French policymaking during the cold war. Archival evidence reveals that as early as 1975 the French finance ministry warned that French risks were excessive; that Poland's growing economic difficulties would render the country unable to repay its debts; and recommended limiting France's financial commitments. The French government, however, decided not only to carry on but also to increase lending, in order to support its political objective of using economic and financial means to relax East-West tensions. This article illustrates how creditors play a part in sovereign debt crises by voluntarily turning a blind eye to a country's growing inability to repay its debts, and thus reinforce a vicious circle of indebtedness.
\end{abstract}

Keywords: debt crisis, Poland, France, cold war, export credit

JEL classification: $\mathrm{N}_{24}, \mathrm{~N}_{44}, \mathrm{~N}_{14}$

Sovereign defaults attract considerable scholarly attention. Debt rescheduling and renegotiation, structural adjustment programmes and incentives for a debtor to

Professor E. Mourlon-Druol, Adam Smith Business School, Gilbert Scott Building, University of Glasgow, University Avenue, Glasgow Gi2 8QQ; email: emmanuel.mourlon-druol@glasgow.ac.uk. I would like to thank Sebastian Alvarez, Stefano Battilossi, Juan H. Flores, Angela Romano, Catherine Schenk, Mary O'Sullivan and two of the three anonymous reviewers for their constructive and helpful comments. This research was part of the Uses of the Past in International Economic Relations (UPIER) project, financially supported by the HERA Joint Research Programme 3 Uses of the Past, which is co-funded by AHRC, AKA, BMBF via DLR-PT, CAS, CNR, DASTI, ETAg, FWF, FRS-FNRS, FWO, FCT, FNR, HAZU, IRC, LMT, MIZS, MINECO, NWO, NCN, RANNÍS, RCN, SNF, VIAA and the European Commission through the European Union's Horizon 2020 research and innovation programme under grant agreement No. 649307. 
default are all scrutinised in detail. But as Juan Flores (2016) recently noted, the predominant focus remains on analysing the responsibilities and behaviour of the debtor in the crisis. Incentives for a creditor to lend excessively are more rarely taken into detailed consideration in the overall analysis of the causes of a debt crisis. With respect to the Latin American debt crisis of I982, Altamura and Flores (2016) thus notice that most studies still place responsibility for the crisis with the macroeconomic deterioration of the situation in the respective countries, rather than with possible incentives from the governments and banks to have lent excessively to Latin American countries in the first place (two exceptions are Wellons I987; Devlin I990).

The same reasoning holds in the case of the Polish debt crisis. In March I98 I, the Polish authorities notified their Western creditors that they were no longer able to repay their debts. The consensual view to explain why Poland ran into financial troubles centres on Polish first secretary Edward Gierek's policy to attract Western financial investments from the early I970s. In spite of succeeding in gaining significant financial inflows into Poland, the Polish authorities proved unable to reform the country's economic system. The worsening of the macroeconomic context and the deterioration of Poland's terms of trade with the West rendered Poland unable to gain the hard currency it needed to repay its external debt (Poznanski I986; Siwiński I988; Kamiński I99I; Lissakers I993; Kotkin 20Io, pp. 81-6; Jarząbek 20I4). But the fact that credit may have flowed into Poland in excessive quantity because of the creditors' conscious disregard of those Polish economic weaknesses is overlooked. Kotkin (20IO, p. 85) thus explains that 'the I973 oil shock, on top of the inherent wastefulness and nonmarket rigidity of planning, bludgeoned the borrowing strategy [of the Polish authorities]', but does not develop the idea that the West may have lent excessively. While Lissakers (1994, pp. 4-5) does mention the eagerness of banks to lend to Poland, she does not discuss the governments' degree of awareness of Poland's difficult economic situation, and the most important factor identified remains the failure of Gierek's strategy. Poznanski is even more straightforward in putting the blame on Poland alone: 'it was Poland's inability to institute an adjustment policy which worsened the crisis far beyond what one would have predicted on the basis of Gierek's policy alone' (I986, p. 455). Similarly, Zloch-Christy writes that 'the "new development strategy" failed because of the systemic inability of the Polish planning authorities to implement it properly', and later adds some external factors including oil-price shocks, deteriorating terms of trade, global recession, or credit squeeze (1987, pp. 76, 82-90). The entire section on the 'causes and consequences of the crisis' in Poland in Marer and Siwiński (I988) does not consider the creditors' lending at unsustainable levels, nor does a book published nearer to the outbreak of the crisis in 1985 (Landau and Tomaszewski I985, p. 320). In short, the onus of the financial debacle primarily lies on Poland. Linked to this is the fact that the literature focuses on the debt crisis sensu stricto, that is, the debt renegotiations and rescheduling starting in I98I. Analysis of the Polish travails starts once the accumulation of debt had already become unsustainable. Bartel (20I7; see also James I996, p. 36I; Boughton 200I, pp. 320-I) thus analyses the role of banks in the I980-2 period, once the Polish debt 
situation was already critical. The changing context that followed the imposition of martial law in December I98I, with its significant economic, political and cold war implications, further contributes to overshadow the importance of the financial context pre-I98I (Sjursen 2003; Domber 20I4; Tavani 20I4).

Two exceptions to this are Portes' article in Foreign Affairs and Badel's work on French foreign trade diplomacy. ${ }^{1}$ Both identify I 977 as the turning point when a few economists and policymakers would have started to worry about the situation. In his July I977 article, Portes wrote that 'The economic strategy chosen in I97I-2 is largely compromised, and with it Poland's ability to avert debt rescheduling at the end of the decade' (p. 767). An article in Institutional Investor lists other such cases of economists warning of Poland's difficulties (Baird and Delamaide I982). Were these economists really alone in thinking so? In an article on risk and the French state, Badel (20 Iob, p. I30) deals very briefly with the case of Polish debt. Badel focuses on the attitude of the Élysee palace alone, and does not provide evidence that other parts of the French administration were aware of the situation. Badel does not cover the reactions of the finance and foreign ministries, and concludes that until 1977 the French authorities were not alarmed about the situation, a point this article aims to qualify. ${ }^{2}$

By contrast, this article reveals that not only the French Treasury but also the French embassy in Warsaw alerted their respective ministries to the economic difficulties of Poland and its struggle to service its debt as early as I975 and I976 respectively. From then on, the French Treasury regularly warned the French minister of economics and finance about the gradual improbability that Poland would honour its debt commitments in time, if at all. This goes against Portes' claim that 'this new East-West economic interdependence now clearly demands the policy analysis which ideally should have preceded it' (I977, p. 75I). The French government did develop its own policy analysis before getting involved, but consciously chose to prioritise political objectives associated with supporting Poland over the economic and financial risks taken. A close look at the French government's detailed economic analysis of the Polish situation only reinforces the argument that French lending was done at unsustainable levels, and that the French government turned a blind eye to the unsustainability of the Polish situation to preserve the longer-term détente process. Situated at the crossroads of three fields of research - sovereign lending, cold war history, and history of French international economic relations - this article contributes to bringing out the tension between the economic and political priorities in French policymaking in a cold war world. In order to retrace French foreign policymaking and thinking on the topic, this article is based on archival material from the several divisions of the French administration involved in the policymaking process,

1 In his recent archive-based account Bartel also writes that 'hints of looming financial catastrophe began to emerge in I977'; see Bartel 20I7, pp. 80-I.

2 In her book on French commercial diplomacy, Badel further develops this case but mostly to present the early development of Franco-Polish economic relations, and use the same material and conclusions as in the article; see Badel 2010a, pp. 344-9, 373-7. 
namely, two divisions of the French foreign ministry (Direction Europe, DE, and Direction des Affaires économiques et financières, DAEF), two divisions of the finance ministry (Trésor, and Direction des Relations Économiques Extérieures, DREE), as well as the Banque de France. ${ }^{3}$ Section II situates the French case within the wider context of Western lending to the East. Section III briefly analyses the early development of economic and financial connections between France and Poland from the late I950s until Gierek's new economic policy. Section IV scrutinises the setting up of the first Franco-Polish financial protocol of 1972 , and the start of French government-backed lending to Poland. Section v delves into the question of the renewal of the I972 financial protocol for a further three-year period, from I975 to I978, and highlights the French government's awareness of Polish financial difficulties. The sixth section looks into the final stages before the Polish authorities' official announcement in March I98 I that they could not reimburse their debts; Section VII concludes.

\section{II}

Lending to Poland occurred against the backdrop of the cold war's détente process. The cold war, understood as the competition between the capitalist West and the socialist East, lasted from the late i940s until i99 I (Westad 2018, pp. I-3). From the late I960s until the late I970s, the two superpowers - the United States and the USSR - underwent a period of relaxation of tensions known as détente. The process of détente encouraged the development of links - economic, financial, cultural - across the Iron Curtain. Détente highlighted that the division of the world into blocs was not permanent. In the specific European context, Western and Eastern European countries were keen to overcome the cold war order by developing such links. In particular, they were keen to do this regardless of the superpowers' confrontation (see, for instance, Loth 2002; Romano 2009; Bange and Villaume 2017).

Intensifying commercial and financial relations was thus part and parcel of that strategy. Several Western countries were involved in lending to Poland. Banks and governments from France, Italy, the UK, the US and West Germany were among the most important lenders (Cohen 1986; Frieden 1987). Against the background of détente, Western governments were keen to see Eastern European countries borrow on international capital markets, and supported them in doing so; while the regimes of Eastern Europe were seeking finance in order to improve living standards (Loth 20IO, pp. 5I9-22; Bartel 20I7, pp. 79-80). In each of the Western countries, tensions equally existed between the fulfilment of their economic and political objectives, the full analysis of which goes well beyond the scope of one single journal article.

But why look specifically at France and Poland? Poland was the largest Eastern European country. Among the various creditors involved in Poland, France stood

3 The French exports credit guarantee department (COFACE, Compagnie française d'assurance pour le commerce extérieur) did not have autonomous decision-making power. On COFACE, see Saul I986, 2002. 
Table 1. Indebtedness of Eastern countries towards France, on 30 June 1980 (in billion francs)

\begin{tabular}{|c|c|c|c|}
\hline & $\begin{array}{l}\text { Guaranteed } \\
\text { credits }\end{array}$ & $\begin{array}{l}\text { Non- } \\
\text { guaranteed } \\
\text { credits }\end{array}$ & $\begin{array}{l}\text { Total gross } \\
\text { indebtedness }\end{array}$ \\
\hline USSR & I 7,873 & 4,400 & 22,273 \\
\hline Poland & 9,448 & 7,300 & I 6,748 \\
\hline GDR & 5445 & 5,950 & I I, 395 \\
\hline Romania & 2,385 & 5,330 & 7,7 I 5 \\
\hline Hungary & $2 \mathrm{I} 7$ & 3,670 & 3,887 \\
\hline Bulgaria & $6 \mathrm{I} 7$ & I,5 IO & $2, \mathrm{I} 27$ \\
\hline Czechoslovakia & 465 & $\mathrm{I}, 460$ & 1,925 \\
\hline Total (COMECON countries) & 36,450 & 29,620 & 66,070 \\
\hline Yugoslavia & 4,704 & 4,050 & 8,754 \\
\hline
\end{tabular}

Source: AMAE, DE/5442, Aide à la Pologne, 30 March I98 I .

out for its large use of export credit guarantees. The use of export finance meant the strong implication, and backing, of the French state in financial transactions since the state insures against non-payment. By I980, in terms of share of guaranteed credits on total gross indebtedness towards France, Poland was indeed second only to the USSR (Table I). Finally, France was one of the chief advocates of the détente process. French president Charles de Gaulle was a vigorous proponent of the détente policy, and supported an independent foreign policy aimed at developing France's connections with Eastern European countries. France and Poland had a long tradition of political friendship that some date back to the Napoleonic period, and both countries enjoyed numerous cultural links. ${ }^{4}$ Of all Eastern European socialist countries, Poland was the one with which the French government claimed to have the closest and the best relations. From a Polish point of view, the strategy was to open up to the West, but also to slow down the West German penetration induced by this opening and compensate for it with the greater involvement of the traditional French ally. ${ }^{5}$ In I972, West Germany's market share in Poland was no less than 40.2 per cent, while that of all other Western countries was between 7.9 (Japan) and I6.8 per cent (UK) (Table 2). Polish authorities also appreciated France's avowedly independent foreign policy, in that they considered it was a reliable resource in the superpower confrontation. As the French foreign ministry put it: 'in their concern to leave the tête-à-tête with the USSR, they [the Poles] see in us the least

${ }^{4}$ See, for instance, Pomian 200I; Boel 20I0. Polish first secretary Edward Gierek was raised and educated in France, and Michel Poniatowski, one of the politicians closest to Giscard, was of Polish descent.

5 Archives du Ministère des Affaires étrangères (hereafter AMAE), DE-CE/432, Relations économiques franco-polonaises, 27 November 1973. 
Table 2. Trade between Poland and main Western countries (million dollars)

\begin{tabular}{lccc}
\hline \hline & & & \\
& \multicolumn{1}{c}{ I972 } & & \\
\cline { 2 - 4 } & Import from Poland & Export to Poland & Market share \% \\
\hline West Germany & 306 & 450 & 40.2 \\
France & I I 6 & I 50 & I 3.4 \\
UK & I 77 & I 88.4 & I 6.8 \\
Italy & 207 & I 27.2 & I I.3 \\
US & I 39 & I I 2.8 & IO. I \\
Japan & 34 & 88.8 & 7.9 \\
Total & I,O79 & I, I I 7.2 & IOO \\
\hline \hline
\end{tabular}

Source: Centre des Archives économiques et financières (hereafter CAEF), B2645 I/7, Ministère de l'économie et des finances, Le commerce extérieur polonais et les relations commerciales franco-polonaises, undated (c. I975).

compromising European partner, due to the attachment we show to our national independence'. 6

Why was lending to Eastern European countries in general, and Poland in particular, so appealing to the West? Many assumptions about Eastern European regimes, stereotypical but widespread, played an important role in the decision of Western countries and banks to lend. Among such assumptions feature first the perception about the alleged rock-like stability of communist regimes, which reassured lenders. Second, the reputation of these regimes for fiscal conservatism and perfect debt-servicing track records further made lending to Eastern Europe look like a safe investment (Terry I988). Third, French authorities did not rank Poland in the classic category of 'developing country', which might have instilled more caution in their thinking about it. ${ }^{7}$ Finally, the so-called umbrella theory, according to which the Soviet Union would come to the rescue were an Eastern European country running into trouble, provided a sort of safety net in the mind of Western investors. ${ }^{8}$

The use of specific financial mechanisms (export credit guarantees and financial credits) to support the economic (search for new markets) and political (détente) motivations for French investment in Poland contributed to minimise the risk taken by firms and banks. The direct consequence of the French government's

6 AMAE, DE/460o, Direction des affaires politiques (hereafter DAP), Europe, Relations francopolonaises, 26 November I976.

7 AMAE, DE/ 5438, Ministère des relations extérieures, Direction d'Europe (hereafter DE), Situation économique de la Pologne, 6 July i98 I.

8 Sjursen 2003, p. 27; and 'Paper by East European and Soviet Department on the "Umbrella Theory": Soviet reaction to the possibility of a Polish default, 26 March I98I', in Tombs and Smith 20I7, pp. $\mathrm{I}_{30}-4$. 
predominant use of export credit guarantees was that its decision may have relied on a broader set of factors, including grand strategy (détente in a cold war world) and a more classic cost-benefit analysis (support the finding of new markets for French exports). Evidence of this can be found in the reflections within the French foreign ministry itself. Shortly after Poland announced to its Western creditors in I98 I that it was not able to repay its debts, a note from the French foreign ministry, outlining the reasons why the French government should help Poland, read: 'There is a moral reason [why France should help Poland]: we have a degree of responsibility in the current situation, in that the megalomaniac policy of Edward Gierek has been facilitated by the French financial generosity [largesse] in the period I975-78 in particular.' The French therefore saw themselves as sharing a degree of responsibility in the making of the Polish debt crisis, which is a rare acknowledgement coming from a lender in such a situation.

From the I960s the French government started to actively promote French exports, through a mixture of political and commercial diplomacy. ${ }^{10}$ Against the backdrop of cold war détente, Eastern European countries in general and Poland in particular were important parts of that strategy (see, for instance, Bouillon 20I6). In the same period, first secretary Gomulka had already started the process of Poland's reopening to the West, before Edward Gierek (Jarząbek 20I4). This nascent economic cooperation materialised with the signature of several trade agreements in the I96os between the two countries, which paved the way for the more intense cooperation of the Gierek era during the I970s. But importantly in comparison with the later period, as Jarząbek (2014, p. 296) notes, 'Gomulka was not eager to finance modernisation with the use of loans and credits', unlike Gierek from I970.

At the earliest, the French government's interest in Poland dates back to I958, when Paris considered financing a project for a coal mine. ${ }^{11}$ France was the first Western country to sign such an agreement with Poland in July I963 (Jarząbek 20I4, p. 295). Two other agreements followed suit, in October I965, and then in May I966. ${ }^{12}$ These agreements were part of a wider pattern that the French government was pursuing at the time and dubbed 'neo-bilateralism' (Badel 2006, p. I78). The French government was encouraging an increase in bilateral economic cooperation explicitly aimed at supporting French exports. De Gaulle's official visit to Poland

9 AMAE, DE/ 5442, Ministère des relations extérieures, DE, Sous-direction d'Europe orientale, Les pays occidentaux et l'aide à la Pologne, 6 August I98 I .

10 For a detailed analysis of this see Badel 2012, 2009, 2010a.

11 But the project was eventually not pursued; see CAEF, B2645 I/7, Compte-rendu de la réunion chez de Margerie le 6 octobre I958 au sujet du financement d'une mine de charbon à coke.

12 AMAE, DE-CE/432, Commission intergouvernementale de coopération économique francopolonaise, Évolution des structures de la coopération économique franco-polonaise, October I973. 
Table 3. Evolution of French trade with Poland (million francs)

\begin{tabular}{|c|c|c|c|c|c|c|c|c|}
\hline Year & I965 & I966 & I967 & I968 & I969 & I970 & I97 I & I972 \\
\hline Imports & I 5 I & 206 & $22 \mathrm{I}$ & 215 & 302 & 377 & $55 \mathrm{I}$ & 595 \\
\hline Exports & I 76 & 332 & 305 & 4IO & 423 & $45 \mathrm{I}$ & 466 & 766 \\
\hline Volume & 327 & 538 & 526 & 625 & 725 & 828 & I,OI 7 & $\mathrm{I}, 36 \mathrm{I}$ \\
\hline Balance & +25 & $+\mathrm{I} 26$ & +84 & +195 & $+\mathrm{I} 2 \mathrm{I}$ & +74 & -85 & $+{ }_{\text {I } 7 \mathrm{I}}$ \\
\hline & I973 & I974 & & I975 & \multicolumn{2}{|c|}{$1976^{a}$} & I977 & I978 \\
\hline & 739 & $\mathrm{I}, 26 \mathrm{I}$ & & I,, 5 I I & \multicolumn{2}{|c|}{ I, 849} & $2,09 \mathrm{I}$ & 2,438 \\
\hline & $\mathrm{I}, \mathrm{I} 8 \mathrm{I}$ & $\mathrm{I}, 8 \mathrm{OI}$ & & 2,680 & \multicolumn{2}{|c|}{3,200} & $2,37 \mathrm{I}$ & $2,27 \mathrm{I}$ \\
\hline & I920 & 3,062 & & 4, I9I & \multicolumn{2}{|c|}{5,049} & 4,462 & 4,709 \\
\hline & +442 & +540 & & $+\mathrm{I}, \mathrm{I} 69$ & \multicolumn{2}{|c|}{$+\mathrm{I}, 35 \mathrm{I}$} & +280 & $-\mathrm{I} 67$ \\
\hline
\end{tabular}

${ }^{a}$ Data available on I I months only.

Source: AMAE, DE-CE/43 I to 433, author's calculations based on multiple notes.

in 1967 , a year after his visit to the USSR, contributed to relaunching Franco-Polish relations politically. ${ }^{13} \mathrm{New}$ agreements between the two countries followed suit in I969. ${ }^{14}$ They provided privileged credit conditions, and contributed to momentarily reducing the Polish trade deficit (Table 3 ).

Coming to power in I970, Gierek decided on a new economic strategy for Poland. Against the backdrop of domestic economic dissatisfaction, Gierek decided to boost Poland's economic growth by improving the supply of consumer goods and food, and thus raising the standard of living. Large-scale borrowing from the West - something that Gomulka was reluctant to accept - would be the cornerstone of this new economic strategy. Over the years, Polish policy did not just consist of opening up to the West, but also, within that framework, the aim was to compensate for West Germany's influence by developing relations with other Western European countries, and France in particular. Polish authorities were thus eager to sign bilateral multi-annual industrial, scientific and technical 'cooperation agreements' with Western European countries (Jarząbek 20I4, pp. 30I-2). From I969, the Commission of the European Economic Community (EEC) took over the competence to sign new trade agreements with EEC member states (Romano 20I4). ${ }^{15}$ Such bilateral agreements were therefore carefully drafted so as to circumvent the EEC's Common Commercial Policy (CCP). ${ }^{16}$

13 AMAE, DE/460o, DAP, Europe, Relations franco-polonaises, 26 November I976.

14 AMAE, DE-CE/43 I, DAEF, La coopération économique et industrielle franco-polonaise, I9 April I97I.

15 The different Franco-Polish protocols have been negotiated as part of a special procedure agreed upon for relations with Eastern European countries by the EEC Council on I6 December I969.

16 On the question of circumventing EEC constraints, see Badel 20Ioa, pp. $35 \mathrm{I}-5$. 


\section{IV}

What framework did the French and Polish governments agree upon to formalise their financial relations, and materialise Gierek's policy towards the West? After I972 and the materialisation of Gierek's I970 new policy with the signature of concrete cooperation agreements between the two countries, long-term cooperation was increasingly tied to financial facilities. The Polish government asked the French to conclude a long-term (Io-year) cooperation agreement as France did with the USSR. ${ }^{17}$ The agreement was signed on 9 June 1972 in Warsaw, and nicknamed Gierek I. The agreement provided a general framework aimed at encouraging greater Franco-Polish cooperation in all sorts of economic, industrial, scientific and technical domains. The economic analysis provided ahead of the first meeting of the newly created Mixed Commission for Franco-Polish Economic Cooperation gathering French and Polish ministers was already very cautious: 'Fragile inside, Polish economic development becomes more and more dependent on an external contribution while its exporting capacity does not allow a satisfactory balance. ${ }^{\text {, }}$

In October I972, a confidential financial protocol came to complement the June I972 agreement, and set out the financial conditions for Franco-Polish relations. Financial conditions were, as in the I969 agreement, privileged. By the same mechanism (lowering the risk premium on export credit), the rate for credits up to five years was O.I 8 per cent lower than the regular rate, while credits up to seven years and beyond were 0.30 per cent lower than the regular rate. The financial protocol of 1972 originally included credits up to I.5 billion francs under privileged conditions (at rates lower than the regular ones). This amount was increased to 2.25 billion in October I973, then to 4.5 billion in April I974. ${ }^{19}$ The French government thus agreed to triple the overall amount of credits within just I 8 months.

When it came to credit conditions, a constant and successful tactic of the Polish authorities was to play Western countries off against each other. On the occasion of the first meeting of the Franco-Polish commission in 1973 in Poland, Giscard paid a visit to Gierek in Warsaw. ${ }^{20}$ Gierek noted that the French were perceived as 'excessively rigid' in contract negotiations, and offered conditions that were inferior to those of their competitors. During the meeting of the Franco-Polish commission, Polish authorities asked for easier financial conditions than those included in the

17 AMAE, DE-CE/43 I, Accord de coopération à long terme avec la Pologne, 7 July I972. See also Badel 20Ioa, pp. 373-7.

18 CAEF, B44076, Commission intergouvernementale de coopération économique franco-polonaise, Évolution et situation de l'économie polonaise, October I973.

19 AMAE, DE-CE/433, DAEF, Accords bilatéraux, IIème session de la Commission intergouvernementale de coopération économique, 23 January 1975.

20 AMAE, DE-CE/432, Telegram no.I053/I058, Audience accordée à Giscard par Gierek, 27 October I973. 
October 1972 financial protocol, and Giscard agreed. ${ }^{21}$ In particular, Giscard granted a 750 million francs extension to the I.5 billion franc credit if needed, something that the Poles did not even ask for. ${ }^{22}$ Giscard explained that this 50 per cent increase corresponded to the rhythm in the increase of trade relations between the two countries. Polish participants were of course delighted.

The 1972 protocol was due to expire on 3 I December I975. On 22 January I975, Polish authorities set out their requests, and asked in particular for further improved financial conditions for particularly large projects, while obviously the first protocol had not expired yet. The French foreign ministry agreed to start negotiating a new financial arrangement, and did not seem unsympathetic to Polish requests. But in taking stock of the Polish situation as the question of the renewal of the I972 protocol was raised, the French finance ministry voiced concerns. ${ }^{23}$ Head of the Trésor Jacques de Larosière and the head of the DREE Bertrand de Morel noted that it would be wise to wait until the end of 1975 and the actual end of the first protocol to discuss a new one that would start in early 1976. They realised that for political reasons it may not work that way, in which case they recommended a renewal of the same dispositions as the 1972 protocol. They explained that these conditions were already good for Poland, and would not lead to a degradation of France's credit conditions.

De Larosière alone voiced a second concern. The head of the Trésor noted that the conditions of the 1972 protocol were exceptional, and based on the Polish promise of the sale of copper, which never materialised. ${ }^{24}$ Renewing that exceptional agreement would already be a considerable effort from a French perspective. De Larosière further explained that the French sectors that exported to Poland were currently saturated, which would further increase the risk. De Larosière concluded that his preference went for a simple renewal of the 1972 agreement for a limited duration of two years.

After a few months of negotiations, both sides simply agreed to extend for three years the validity of the 1972 protocol. The new protocol, nicknamed 'Gierek 2', covered the I976-8 period, for a total of 5 billion francs, later further increased to 7 billion. French reports consistently described the new agreement as a reproduction of the 1972 protocol, while in effect it was much more than this. The original I972 protocol only envisaged a total of I.5 billion francs, which was subsequently increased to 2.25 in October I973, and then 4.5 in April I974. However, in the framework of the agreement on coal, the Polish and French government reached a com-

21 AMAE, DE-CE/432, Telegram no. I076/I079, Première session de la commission intergouvernementale franco-polonaise de coopération économique, 29 October I973.

22 AMAE, DE-CE/432, Première session de la commission intergouvernementale de coopération économique franco-polonaise (25-29 octobre I973), 3 November I973.

23 CAEF, B44076, de Larosière and de Morel to minister, Pologne: Conditions de crédit applicables à nos exportations de biens d'équipement, 28 January 1975.

24 Ibid., de Larosière's final comment in his own name. 
promise on the granting of new French financing facilities to Poland. ${ }^{25}$ In addition to the type of facilities existing under the October 1972 agreement (that is, credit lines to purchase semi-manufactured goods and equipment at rates inferior to the regular ones), the French government granted private guaranteed credits of a total of 900 million francs, to be used within a three-year period. The French government granted a greater role to banks under that agreement, as they would no longer be just brokers in the transactions, but would also engage in rollover credits, which would let them take the risk of the transactions. ${ }^{26}$

Once again, the political dimension was very significant. The French foreign ministry kept insisting that the relationship between France and Poland was a special one: 'So frequent meetings, in such a legal framework for a bilateral cooperation, do not exist for any other Eastern European country, except with the USSR, which we can be sure keeps a record of the Franco-Polish meetings and declarations, charters, agreements and protocols. ${ }^{27}$ To increase the ceremonial further, the new protocol was not just signed among civil servants, but between the heads of government in June 1975 in Poland, in order, very consciously, to provide more importance to the event. Giscard wanted to highlight the "exemplary character of relations between both countries and to give to their cooperation a new impulse'. ${ }^{28}$ This new impulse, political as it was, occurred just as the first concerns about Poland's ability to service its debt began to appear.

The equation that Polish authorities needed to solve in order to repay their debts was straightforward. Poland needed to increase its exports in order to gain hard currency, and pay for what it borrowed. The problem resided in the fact that Polish exports did not increase up to the level that was hoped, while Polish imports rose. A way out of this dilemma would have been to slow down imports, and improve exports. But limiting imports was unpopular, while modernisation did not happen to the extent needed to improve Polish exports.

Reports on the evolution of the Polish economy during the period of implementation of the first financial protocol of 1972 were already very cautious. The French foreign ministry observed that: 'A worrying evolution is taking place with regard to the volume of contracts for goods equipment that are concluded. While between I97I and I974 the amount of these contracts was multiplied by ten ... we observed, in 1975 ... that no significant contract has been concluded for more than a year. ${ }^{29}$

25 AMAE, DE-CE/433, Telegram no. 47/55, Réunion de la commission mixte de coopération, 6 February I975.

26 AMAE, DE-CE/433, DAEF, Relations franco-polonaises, Politique de crédit à l'égard de la Pologne, 6 June 1975 .

27 AMAE, DE/460o, DAP, Europe, Relations franco-polonaises, 26 November I976.

28 Ibid.

29 AMAE, DE-CE/433, DAEF, Relations économiques franco-polonaises, 22 April I976. 
In the second semester of I976, both the French Treasury and the French embassy in Warsaw drew attention to the worrying size of French risks in Poland. The French ambassador in Warsaw first warned of the worsening of the Polish financial situation:

External debt - on which we have no certainty - is probably around 7 and Io billion dollars and its service, while it does not reach $20 \%$ of total exports (Io billion dollars) as the Poles repeat to us, nevertheless represents an excessive fraction of the value of the exports to Western creditor countries (4.5 billion) ... Confronted with this situation, the people in charge [in Poland] considered that politics won and froze the situation for a year in the hope that by then confidence will be restored and that some of the measures recently envisaged will have come to fruition ... However, the risk exists of finding oneself in a year in situation politically unchanged and economically worsened and one discerns poorly how decisions adjourned today could be taken then. ${ }^{30}$

In early 1977, the French ambassador in Poland, Louis Dauge, repeatedly highlighted Polish problems. ${ }^{31} \mathrm{He}$ presciently concluded that 'Poland will have to request new loans to foreign governments and banks in order to reimburse the credits that fell due and to finance the deficit of its current account. ${ }^{32}$

Similar concerns came from the Trésor at exactly the same time. In October I976, the Trésor highlighted the fact that Polish indebtedness was 'significant and growing fast'. ${ }^{33}$ The note explained that on 3 I August I976, global outstanding risk at mid and long term was at 6.6 billion francs, of which 5.3 billion was part of governmental protocols. By late November I976, it was at 9.6 billion dollars, that is 6 per cent of French total risks, the third French risk after the USSR and Algeria. ${ }^{34}$ On the occasion of a visit by French trade minister André Rossi to Poland in December 1976, De Larosière took stock of French commitments in that country. De Larosière recalled that Poland not only benefited from exceptional credit conditions, but also from additional advantageous financial help within specific agreements such as those related to coal, the steel industry and cereals. ${ }^{35}$ De Larosière warned that: 'the indebtedness of this country vis-à-vis Western countries ... is at a particularly worrying level. In these conditions, I cannot but recommend the greatest prudence regarding the new Polish requests, that do not seem to me can be taken into consideration at the current moment. 36

On I I January I977, Jacques de Larosière wrote to the French minister of economics and finance expressing his view that 'An increase of our risks on Poland is

30 CAEF, B44076, Telegram no. 917/24, Dauge, La situation en Pologne, I I October 1976.

31 CAEF, B44076, Telegram no. 39/49, Dauge, I 3 January 1977.

32 Ibid.

33 CAEF, B44075, Trésor, Pologne: Situation économique et financière. Relations avec la France, 8 October 1976.

${ }^{34}$ CAEF, B44076, DREE, Commission mixte de coopération franco-polonaise, 2I January 1977.

35 CAEF, B 44076, de Larosière to minister, Pologne: Financement de nos exportations, 7 December I976.

${ }^{36}$ Ibid. 
inappropriate. ${ }^{37}$ De Larosière mentions the record trade deficit of 2.9 billion dollars registered by Poland in I975:

This deficit has been covered by loans and the state of indebtedness of this country is now worrying ...; the burden of external debt vis-à-vis Western countries, which was of 7 billion dollars at the end of 1975 , is now estimated at Io billion dollars, that is, a quarter of the indebtedness in hard currency of the whole of Eastern European countries. As for debt service, it now represents 30 per cent of export revenues. One must conclude that Poland is the real 'sick man' of Europe. ${ }^{38}$

De Larosière explained that the then outstanding risks on Poland represented 6 per cent of the COFACE total risks, while French exports to Poland only amounted to I.2 per cent of French exports. The Polish authorities' use of the euro-currency market to finance Polish imports was another worrying indication, according to the Trésor. ${ }^{39}$ The Trésor referred to data from Morgan Guaranty Trust Company to estimate Poland's use of the euromarkets: 430 million dollars in 1973, 509 in I974, 475 in I975, and estimated at 525 in 1976. The Trésor noted again that French credits were granted 'at particularly favourable conditions which constantly provoke comparable requests from other Eastern European countries' and therefore called for 'moderation in our engagements with this country'. 40

Later in the same year, in September I977, the Trésor described again the deterioration of the situation in Poland, and the risks this implied for the French government. But this time, the Trésor was more explicit in pointing out French responsibilities in the worsening of the situation. 'This country has benefited in a relatively short period from considerable Western credits and loans ... Western banks doubting of the solvability of Poland are more and more reluctant to grant loans. When Poland realises a loan, it is asked to pay an interest rate that is above I. $5 \%$ to the one practiced on the euro-markets. ${ }^{, 41}$ The Trésor then explicitly spelled out the political and commercial incentives for the French government to neglect Polish economic difficulties: 'In spite of the continued deterioration of the Polish financial situation, France (and to a lesser extent other Western countries) has been until then ready to consent, for political as much as commercial reasons, to more and more significant facilities in order to help Poland mitigate the crisis of its external payments. $^{42}$

From then on, the French embassy in Poland and the French Treasury would not cease warning the rest of the French government of the dangers of the evolution of the

37 CAEF, B44075, Trésor to minister, Pologne: Financement de nos exportations, I9 January I977.

38 Ibid.

39 CAEF, B44076, Note Trésor, Pologne: Situation économique et financière. Relations avec la France, I9 January 1977.

40 Ibid.

41 CAEF, B44076, Service des affaires internationales, Pologne: situation financière, September I977.

42 Ibid. 
Polish economic situation. What changed from I978 was the sense of alarm on the French side. In March, de Larosière and de Morel wrote to the deputy economics minister Robert Boulin:

the two directions [Trésor and external economic relations] are preoccupied by the amount and the growth of our risks with this country [Poland], which risks experiencing difficulties in honouring its commitments over the coming years, given the importance of the debt service in convertible currencies. They consider that the greatest prudence should be imposed with regard to new commitments on this country, the financial situation of which is fragile. For its part, the Trésor asks that no new facility ... be granted to Poland, until its financial situation has improved. ${ }^{43}$

On this last request, a handwritten note indicates 'defeated' in the margin. And indeed in communicating his final decision, Boulin indicated that Poland 'must be placed in the category of countries under surveillance', without referring to further detailed instructions. ${ }^{44}$ The only substantial change was thus to place Poland among the countries for which the management of credit insurance risk was the object of a specific surveillance. ${ }^{45}$ The French economics minister further decided in July I978 that any future modification to the credit conditions usually granted could only be decided by the minister himself, and any request for a guarantee for contracts above Ioo million francs should be submitted to him. From this we deduce that before these decisions of March and July, the decision to lend to Poland was subject to a fairly lax procedure.

On I I September I978 Haberer, who in June succeeded de Larosière who became managing director of the International Monetary Fund (IMF), told the French economics minister that 'the situation [in Poland] of external debt is worrying' ${ }^{46}$ To Haberer, the financial dynamic had now changed: 'This indebtedness has reached a level all the more worrying as the solution to many Polish economic problems will only be possible by calling other Western credits, which creates more and more reservations among Western banks.' Polish gross and net indebtedness vis-à-vis Western countries was multiplied by slightly more than four between I973 and I976 (Table 4). Between $\mathrm{I} 975$ and I976 alone, credits with public support almost doubled, while banking credits increased by about 25 per cent (Table 5). Finally, in I978, COFACE was the Western export credit guarantor most involved in Poland by far (Table 6). Overall, Haberer noted that France was the Western country most involved in Poland.

43 CAEF, B44076, de Larosière and de Morel to minister, Fixation des plafonds de risque d'assurance-crédit pour I978, 9 March I978.

44 CAEF, B44076, Boulin to de Larosière and de Morel, Gestion des risques d'assurance-crédit pour I978, I7 March I978.

45 CAEF, B44075, Haberer to minister, Pologne: Situation économique et financière. Relations financières avec la France, I I September I978.

46 Ibid. 
Table 4. Indebtedness of Poland vis-à-vis Western countries (in billion dollars)

\begin{tabular}{lccccr}
\hline \hline & I973 & I974 & I975 & I976 & I977 \\
\hline Gross indebtedness & 2.5 & 4.4 & 7.8 & I I & I 2.5 \\
Net indebtedness & 2.5 & 4.4 & $7 . \mathrm{I}$ & I0.2 & I I.9 \\
\hline \hline
\end{tabular}

Source: CAEF, B44075, Haberer to minister, Pologne: Situation économique et financière. Relations financières avec la France, i I September i978. 'Net indebtedness' calculated by susbtracting deposits in euro-currencies held in Western banks.

Table 5. Debt structure of Poland vis-à-vis Western countries (in million dollars)

\begin{tabular}{lrr}
\hline \hline & I975 & \multicolumn{1}{c}{ I976 } \\
\hline Credits with public support & $2, \mathrm{IOO}$ & 4,000 \\
Banking credits & 4,600 & 5,800 \\
Other credits & $\mathrm{I}, \mathrm{I00}$ & $\mathrm{I}, 200$ \\
Total of gross indebtedness & 7,800 & $\mathrm{I}$ I, 000 \\
Deposits of Poland in Western banks & 700 & 800 \\
Total net indebtedness & $7, \mathrm{IOO}$ & $\mathrm{IO}, 200$ \\
\hline \hline
\end{tabular}

Source: see Table 4 .

There was therefore ample evidence of early, multiple, repeated, detailed and consistent warnings about the difficulties of the Polish economy since I975. These warnings called into question Poland's ability to repay its debts, and pinpointed the excessive involvement and thus the risks of French investments in Poland. But why then did French policy eventually not take into account these warnings? As Badel argues, French president Giscard agreed to take on the economic risk for political reasons (Badel 20 Iob). Giscard's adviser Guy de Panafieu was in particular advocating support for Poland. Guy de Panafieu was a former member of the DREE, whose position was traditionally to encourage and support French exports. De Morel even explicitly stated in a testimony that 'There has been an undeniable political dimension in the risk taken' (Panafieu and de Morel 20 Io, p. I 42). The French foreign ministry's depiction of Poland's situation in I977 confirms de Morel's statement: 'The government of Warsaw has faced since 1976 a number of economic and political difficulties. In order to overcome them, it has obtained the help of the USSR, but has agreed, in counterparty, to align itself even more scrupulously on Soviet positions. ${ }^{47}$ The implicit conclusion of this analysis was that if the French government still wanted to 'detach' Poland from the USSR, it had to continue helping Warsaw financially.

47 AMAE, DE/460o, DAP, Europe, Relations franco-polonaises, 28 March 1977. 
Table 6. Western countries financial engagements in Poland in 1978 (million dollars)

\begin{tabular}{lr}
\hline \hline France (COFACE) & 2,070 \\
UK (ECGD) & I,600 \\
Austria (OKB) & 920 \\
West Germany (Hermes) & 750 \\
Japan (Miti) & $7 \mathrm{I} 2$ \\
Italy (INA) & 559 \\
Sweden (EKN) & 365 \\
USA (Eximbank) & 329 \\
\hline \hline
\end{tabular}

Source: see Table 4 .

While Polish authorities officially announced their inability to repay their debts and called for help in March I98 I, they had already informally contacted Western creditors, and France first, in I979. In July I979, the president of the Polish bank for external trade told the head of the DREE, Michel Freyche, that his country's serious economic difficulties would create problems for the Poles in reimbursing the maturities due in I980 and I98I. This represented the 'first manifestation, albeit unofficial, of the will of the authorities in Warsaw to embark on the road to consolidation' ${ }^{48}$ Giscard swiftly reassured Gierek that France was ready to help Poland. ${ }^{49}$

But the Polish authorities' move in mid I979 must not have come as a surprise to their French creditors. In January I979, Haberer had already explained to the minister that while Poland tried to control the cost of its indebtedness, it was clear that it was not sure whether it would manage to respect the maturities of the debt already contracted. ${ }^{50}$ And just as Giscard promised further financial support to Gierek, the Trésor kept warning about the problems to come. Haberer refused to grant new credits, and highlighted his repeated calls for caution to the minister in the past months: 'Given the indebtedness of Poland we cannot and we must not grant financial credits that are in fact only used to refinance the external debt of Poland. ${ }^{51}$ Haberer provided three reasons to justify his opposition. First, the French government should stop renegotiating the credit conditions several times a year. This point was, essentially, in the spirit of the reluctance shown by the Trésor in 1975 when the question of the renewal of the 1972 financial protocol came to the negotiating table even before the protocol had expired. Second, the Bern Union - the international organisation for export credit was making efforts to ask Western countries to stop providing easy credit to Poland.

48 CAEF, B54303/I, Trésor, Dette extérieure de la Pologne, January i980.

49 CAEF, B 54303 / I, Haberer to minister, Dette de la Pologne: Compte rendu des entretiens de Deniau à Varsovie, 28 September I979.

50 CAEF, B 54303/I, Haberer to minister, Pologne: questions financières, I 7 January I979.

51 CAEF, B44075, Haberer to minister, Crédits à la Pologne, i 8 September I979. 
This point will be explored in further detail below. Third, the last meeting of the Planning Council [Conseil de Planification] on external trade indicated that France's trade policy vis-à-vis Poland should be more cautious given the Polish economic circumstances. As of June 1979, France was the country most involved in Poland concerning guaranteed trade credits: 2.470 billion dollars for France (I0.550 billion francs), 2.0I 3 billion dollars for the UK, I.I67 billion dollars for Italy, 895 million dollars for West Germany, and 672 million dollars for Japan. ${ }^{52}$ Shortly after Poland's request for rescheduling in March I98 I, Haberer again opposed granting new credits, because these were to be announced before agreeing on the scale of Poland's financing needs. ${ }^{53}$

The Trésor's cautious analysis and opposition to granting further help appears in striking contrast with the DREE's reaction. While the DREE certainly did not try to hide Polish difficulties, it did not attempt to discourage French investment in Poland either. ${ }^{54}$ A traditional cleavage surfaced, between the DREE, keen to support French exports, and the Trésor, more cautious in its judgement. The exit from this cleavage was political. Haberer, while duly acknowledging the dilemma between supporting French exports and preserving French financial interests in the Polish debt crisis, lucidly observed: 'The granting of new credits to Poland now undoubtedly constitutes a political act that must be treated as such. It is at the highest political level that the interventions of countries in the framework of a multilateral consultation must be agreed. 55

In the midst of the debates of I979-8 I about whether or not the French government should continue helping to refinance Polish debts, the Polish government kept on playing the competition card among Western lenders regarding credit conditions (Panafieu and de Morel 20I0, p. I44; Jarząbek 20I4, p. 30I). When seeking credits, the Polish government clearly and cleverly played the offers of each country off against each other, and used this competition to its advantage. For instance, in discussing the future of Franco-Polish economic cooperation, the Polish vice-minister for external trade Dlugosz put in perspective the Franco-Polish discussions by describing first the basic framework of the recent agreement signed between West Germany and the USSR, that is, a 25-year agreement, with an initial validity of Io years. ${ }^{56}$ Dlugosz stated that the Polish government would like to agree on something similar with the French government. Freyche replied that he was extremely cautious on this and wanted to work instead on the basis of what already existed between France and Poland. The Trésor also complained that the

52 CAEF, B54303/I, Trésor, Dette extérieure de la Pologne, January i980.

53 CAEF, B 54303/I, Haberer to minister, Nouveaux crédits à la Pologne, I4 September I98 I.

54 CAEF, B44075, DREE, Relations économiques franco-polonaises, I7 September I979.

55 CAEF, B54303/I, Haberer to minister, Nouveaux crédits à la Pologne, I 4 September I98I.

56 CAEF, B44075, Compte rendu des entretiens entre M. Freyche et M. Dlugosz, Warsaw, 6 September I979. 
Polish authorities were constantly asking for concessions, 'in spite of (or because of) the very substantial advantages that we grant them'. ${ }^{27}$

As problems with the sustainability of Polish debt grew, the international framework of coordination concerning export credits looked clearly unsatisfactory. On I6 April I979, president of the Berne Union Manuel Varela wrote to the COFACE. He deplored the fact that credit terms [to Poland]

go far beyond what is normal in international trade. Poland is an important market, where purchases may already be reaching the limit justified by its capacity to earn foreign exchange. This is not normally considered to be a good or sufficient reason for agreeing excessive lengths of credit. To continue to do so can only lead to over-buying by Poland and the risk that the contagion of these abnormal terms will spread to other markets, particularly in Eastern Europe ${ }^{58}$

Varela interestingly pinpointed a sort of 'locked-in' effect: 'The practice of agreeing such terms is now so widespread that no one exporting country can pull back without fear of losing business to others which do not do so. ${ }^{, 59}$ Varela concluded by urging the French government 'to take action so that no agreements conceding abnormal credit terms should be entered into with Poland with a terminal date later than 30 June I98I'. ${ }^{60}$ With the benefit of hindsight, this deadline is of course telling as it was already three months after the Polish authorities said they were unable to repay their debts. The Bern Union was clearly arriving too late to the party. The patent lack of coordination among Western creditors let the Polish authorities skilfully and cleverly benefit from competition among them.

But even more surprising was the inability of the Western creditors to form some sort of cartel among themselves in the first place. Western creditors knew that the Polish authorities were taking advantage of their lack of coordination, and were constantly driving down interest rates, which meant that the risks to the creditors increased. In spite of this, Western creditors proved unable to coordinate their position. At the $\mathrm{G}_{7}$ summit in Puerto Rico, credit conditions were discussed but to no avail (Romano 20I3). Equally inconclusive were discussions about export credit within the remit of the EEC. Haberer warned about the financial consequences for France of this competition among lenders, and called for a greater international coordination, equally to no avail: '[the] question to allow Poland to carry on living on Western credits must not be granted bilaterally in a competitive spirit but within a more multilateral framework and with the concern to share equitably the necessary effort'. ${ }^{61}$

57 CAEF, B44075, Trésor, Situation économique et financière. Questions financières bilatérales francopolonaises, August I979.

58 CAEF, B44075, Varela to COFACE, Poland, i6 April I979.

59 Ibid.

60 Ibid.

61 CAEF, B 54303 / I, Haberer to minister, Nouveaux crédits à la Pologne, I4 September I98 I. 
In spite of the opposition of the Trésor, French financial support for Poland actually continued after the Polish authorities' informal request for rescheduling in July I979. The Polish authorities were eager to get extra funds, while the French government was willing to avoid losses on the other COFACE loans. Haberer and Polish finance vice-minister Krzak signed a confidential Franco-Polish refinancing agreement on I6 November 1979. The agreement concerned two-thirds of the debt maturing in I980. The French government agreed to a banking credit of I,250 billion francs (300 million dollars) guaranteed by COFACE. ${ }^{62}$ The credit was at market rate plus I per cent, that is, around I 3 per cent, for a duration of eight years and reimbursable in nine semestrial payments from 1984 (this included a grace period of 3.5 years). ${ }^{63}$ France was the first Western country to help Poland refinance its debt, and the only country to do this in I980. The agreement was a sort of bridge financing to help Poland over the most difficult period. Instead of the typically subsidised export credit rates from which Poland benefited until then, this new agreement was a government-to-government loan, based on commercial rates. While waiting to find a global solution, an exchange of letters between Haberer and Polish authorities in January I98 I prolonged this agreement under similar conditions. ${ }^{64}$ The French government provided a total of 3 I 2.6 million francs of new credits for the first term of $198 \mathrm{I}$, at the market rate, guaranteed by the COFACE, and to be reimbursed in 4.5 years after a waiting period of 3.5 years. In addition to this, in May I980, the Gierek protocol was renewed for a further five years, under the same preferential conditions. ${ }^{65}$

Overall therefore, in spite of the prospect of rescheduling, the French government decided not only to continue lending to Poland, but to renew existing agreements, and to provide an additional government-to-government bridge loan to help the Polish authorities. The reasons for continued French support remained the same as those advanced to develop economic and financial links with Poland in the first place, and were reiterated when the first indications emerged that Poland was in economic trouble: to detach Poland from the Soviet Union. The French embassy in Warsaw reported in September I98 I that 'Moscow has a clear objective, if not a welldefined strategy to get out of the impasse: the misfortunes of Poland coming from the freedoms it has taken with the system and its opening to the West, the path to recovery naturally goes through the consolidation of socialism domestically and the reinforcement of links with the socialist community externally. ${ }^{66}$ If the French government

62 CAEF, B 54303 /I, Trésor, Exécution de l'accord confidentiel relatif à un crédit financier en faveur de la Pologne (accord Haberer-Krzak du i6 novembre I979).

63 AMAE, DE/ 5443, DE, Situation financière de la Pologne, 28 August I980.

64 AMAE, DE/ 5443, Confidentiel 45/EU, Refinancement de la dette polonaise, 22 January I98 I; AMAE, DE/5438, DE, Situation économique de la Pologne, 6 July I98 I .

65 AMAE, DE/ 5443, DE, Situation financière de la Pologne, 28 August I980.

66 AMAE, DE/ 5438 , Ambassade de France en Pologne, Le conseiller économique et commercial, La crise économique polonaise, I2 September I98 I. 
was to pursue its original strategy of 'detaching' Poland from the Soviet Union, it had thus little choice but to keep supporting Poland financially.

This article showed that French authorities at all levels (foreign ministry, finance ministry, French embassy in Warsaw) were well aware of France's excessive financial involvement in Poland, of Polish economic difficulties, of the associated growing risk that Poland would be unable to repay its debts, and this from I975, that is, well before the Polish authorities revealed their difficulties. The reliability of statistics was at times pointed out, but regardless of this, the broader picture of Polish economic weaknesses left the French government in little doubt that the situation was not sustainable. In spite of repeated early warnings, in particular from the Trésor and the French embassy in Warsaw, the French government not only kept on lending to Poland, but often did so under improved financial conditions, mainly for political reasons. While French calculations always took into account the need to promote French exports in Poland, this was clearly increasingly seen as less important than encouraging the overcoming of the cold war order through the promotion of economic and financial links across the Iron Curtain. From I978 in particular, the Trésor clearly spelled out that the financial risks of French involvement in Poland outweighed the French interest in promoting exports. But as was generally the rule in foreign affairs, the French president and his office had the final word. In the present case, the president consistently disregarded the advice of the Trésor.

The French government's clear-sightedness and awareness of the risks taken in its financial support for Poland highlight the responsibility of the creditor in the dynamics leading to the debt crisis. The French government was conscious of the excessive risks taken in Poland, and in the end played its part in placing the Polish authorities in a situation in which they would not be able to reimburse their debts. This suggests a more balanced account in the making of a debt crisis, moving the focus away from the responsibilities of the debtor, to highlight the contribution of the creditor via excessive lending. The outbreak of the Polish debt crisis meant that the French government had little choice but to carry on helping Poland. In July I98 I the French foreign ministry thus noted that 'the Westerners, besides their political motivations, are condemned to assist her [Poland] if they want one day to recover what was originally invested and keep an economic partner that could become interesting again'. ${ }^{67}$ A final aspect emerging from this account is the considerable weaknesses of international coordination prior to the debt crisis. International cooperation on export credit guarantees was weak, as the Bern Union proved ineffective, and the EEC did not set in place a coordination mechanism. Trade policy was not yet well coordinated at EEC level, and EEC member states used loopholes to circumvent

67 AMAE, DE/5438, DE, Situation économique de la Pologne, 6 July I98 I . 
new legislation. In sum, this account has shown that a creditor and a lack of international coordination contributed importantly to the making of a debt crisis.

Submitted: 3 March 2019

Revised versions submitted: Io July 20I9; 3 October 20I9; 25 October 20I9

Accepted: 26 October 2019

First published online: 4 March 2020

\section{REFERENCES}

ALTAMURA, E. C. and ZENDEJAS, J. F. (20I6). On the Origins of Moral Hazard: Politics, International Finance and the Latin American Debt Crisis of 1982. Geneva: Université de Genève.

BADEL, L. (2006). Pour une histoire de la diplomatie économique de la France. Vingtième siècle. Revue d'histoire, 90, pp. 2 I $69-85$.

BADEL, L. (2009). Diplomatie et entreprises en France au xxème siècle. Les cahiers Irice, 3, pp. IO3-28.

BADEL, L. (20IOa). Diplomatie et grands contrats: l'état français et les marchés extérieurs au xxe siècle. Paris: Publications de La Sorbonne.

BADEL, L. (20Iob). L'état français face au risque politique dans les années I970: les cas polonais, sud-africain et iranien. Les cahiers Irice, 6, pp. I23-40.

BADEL, L. (20I2). France's renewed commitment to commercial diplomacy in the I96os. Contemporary European History, 2I (I), pp. 6I-78.

BAIRD, J. and DELAMAIDE, D. (1982). The lessons of Poland. Institutional Investor, January.

BANGE, O. and VILlaume, P. (eds.) (2017). The Long Détente: Changing Concepts of Security and Cooperation in Europe, 1950s-1980s. Budapest: Central European University Press.

BARTEL, F. (20I7). Fugitive leverage: commercial banks, sovereign debt, and cold war crisis in Poland, I980-I982. Enterprise \& Society, I8 (I), pp. 72-I07.

BOEL, B. (20I0). French support for Eastern European dissidence, I968-I989. In P. Villaume and O. A. Westad (eds.), Perforating the Iron Curtain: European Détente, Transatlantic Relations, and the Cold War, 1965-1985. Copenhagen: Museum Tusculanum Press, University of Copenhagen.

BOUGHTON, J. M. (200I). Silent Revolution: the International Monetary Fund, 1979-1989. Washington, DC: International Monetary Fund.

BOUILLON, P. (2016). Le prix de la détente? La politique française en Hongrie et en Roumanie (1968-1977). Rennes: Presses Universitaires de Rennes.

COHEN, B. J. (1986). In Whose Interest? International Banking and Foreign Policy. New Haven, CT: Yale University Press.

DEVlin, R. (1990). Debt and Crisis in Latin America: The Supply Side of the Story. Princeton, NJ: Princeton University Press.

DOMBER, G. F. (2014). Empowering Revolution: America, Poland, and the End of the Cold War. Chapel Hill, NC: University of North Carolina Press.

FLORES ZENDEJAS, J. (20I6). Capital markets and sovereign defaults. In C. R. Schenk, Y. Cassis and R. Grossman (eds.), The Oxford Handbook of Banking and Financial History. Oxford: Oxford University Press.

FRIEDEN, J. (1987). Banking on the World: The Politics of American International Finance. New York: Harper and Row.

JAMES, H. (1996). International Monetary Cooperation since Bretton Woods. Washington, DC, and Oxford: International Monetary Fund and Oxford University Press,

JARZABEK, W. (20I4). Polish economic policy at the time of détente, 1966-78. European Review of History: Revue Européenne d'histoire, 2I(2), pp. 293-309.

KAMINSKI, B. (199I). The Collapse of State Socialism: The Case of Poland. Princeton, NJ: Princeton University Press. 
KOTKIN, S. (20I0). The kiss of debt: the East Bloc goes borrowing. In N. Ferguson, C. S. Maier, E. Manela and D. S. Sargent (eds.), The Shock of the Global: The 197os in Perspective. Cambridge, MA: The Belknap Press of Harvard University Press.

LANDAU, Z. and TOMASZEWSKI, J. (I985). The Polish Economy in the Twentieth Century. Beckenham: Croom Helm.

LISSAKERS, K. (I993). Banks, Borrowers and the Establishment: A Revisionist Account of the International Debt Crisis. New York: Basic Books.

LISSAKERS, K. (I994). The Polish Debt Crisis of 1981-1982. Pew Case Studies in International Affairs. Washington, DC: Institute for the Study of Diplomacy.

LOTH, W. (2002). Overcoming the Cold War: A History of Détente, 1950-1991. London: Palgrave Macmillan.

LOTH, W. (20I0). The cold war and the social and economic history of the twentieth century. In O. A. Westad and M. P. Leffler (eds.), The Cambridge History of the Cold War, vol. 2: Crisis and Détente.. Cambridge: Cambridge University Press.

MARER, P. and SIWINSKI, W. (I988) Creditworthiness and Reform in Poland: Western and Polish Perspectives. Bloomington and Indianapolis: Indiana University Press.

PANAFIEU, G. DE and LARRERA DE MOREL, B. (20Io). Table ronde. Les cahiers Irice, 6, pp. I 4 I -7 .

POMIAN, G. (200I). Le rôle politique de l'émigration polonaise en France depuis I945. Matériaux pour l'histoire de notre temps, $\mathbf{6 I}(\mathrm{I})$, pp. 62-8.

PORTES, R. (I977). East Europe's debt to the West: interdependence is a two-way street. Foreign Affairs, 55(4) 75I-82.

POZNANSKI, K. (I986). Economic adjustment and political forces: Poland since I970. International Organization, 40(2), pp. 454-88.

ROMANO, A. (2009). From Détente in Europe to European Détente: How the West Shaped the Helsinki CSCE. Brussels: Peter Lang.

ROMANO, A. (2013). G7 summits, European Councils and East-West economic relations (I975-I982). In E. Mourlon-Druol and F. Romero (eds.), International Summitry and Global Governance: The Rise of the G7 and the European Council, 1974-1991. Abingdon: Routledge.

ROMANO, A. (20I4). Untying Cold War knots: the EEC and Eastern Europe in the long I970s. Cold War History, $\mathbf{4}$ (2), I 53-73.

SAUL, S. (I986). La COFACE: des opérations avec garantie de l'État au risque pays. Les cahiers Irice, 6, pp. I69-95.

SAUL, S. (2002). L'État et l'assurance des risques à l'exportation: la COFACE (I946-I966). Histoire, économie et société, $\mathbf{2 I}(3)$, pp. 357-75.

SIWINSKI, W. (1988). Why Poland lost its creditworthiness In W. Siwiński and P. Marer (eds.), Creditworthiness and Reform in Poland: Western and Polish Perspectives. Bloomington and Indianapolis: Indiana University Press.

SJURSEN, H. (2003). The United States, Western Europe and the Polish Crisis: International Relations in the Second Cold War. New York: Palgrave Macmillan.

TAVANI, S. (20I4). The détente crisis and the emergence of a common European foreign policy: the 'Common European Polish Policy' as a case study. In C. Hiepel (ed.), Europe in a Globalising World: Global Challenges and European Responses in the 'Long' 1970s. Baden-Baden: Nomos.

TERRY, S. M. (I988). External debt and the Polish leadership. In W. Siwiński and P. Marer (eds.), Creditworthiness and Reform in Poland: Western and Polish Perspectives. Bloomington and Indianapolis: Indiana University Press.

TOMBS, I. and SMITH, R. (eds.) (20I7). The Polish Crisis and Relations with Eastern Europe, 1979-1982: Documents on British Policy Overseas, series III, vol. X. Abingdon: Routledge.

WELlONS, P. A. (I987). Passing the Buck: Banks, Governments, and Third World Debt. Boston, MA: Harvard Business School Press.

WESTAD, O. A. (2018). The Cold War: A World History. London: Penguin Books.

ZLOCH-CHRISTY, I. (I987). Debt Problems of Eastern Europe. Cambridge: Cambridge University Press. 